\section{RePort of NagaruUnasagar RACER Coluber BHOLANATHI SHARMA, 1976 (SQUAMATA: SERPENTES: COLUBRIDAE) FROM THE GINGEE HILLS, TAMIL NADU, INDIA}

\author{
Utpal Smart ${ }^{1}$, Eric N. Smith ${ }^{2}$, B.H.C.K. Murthy ${ }^{3}$ \& \\ Arun Mohanty ${ }^{4}$
}

${ }^{1,2}$ Amphibian and Reptile Diversity Research Center, Department of Biology, University of Texas at Arlington, Texas 76019-0498, USA

${ }^{3}$ Zoological Survey of India, Prani Vigyan Bhawan, M-Block, New Alipore, Kolkata, West Bengal 700053, India

${ }^{4}$ Sri Aurobindo Ashram, Pondicherry 605002, India

1 usmart@uta.edu (corresponding author), 2e.smith@uta.edu,

${ }^{3}$ drbhckmurthy31@rediffmail.com, ${ }^{4}$ arun.mohanty@gmail.com

The Nagarjunasagar Racer (or Sharma's Racer) Coluber bholanathi Sharma, 1976 was described based on three specimens (one male holotype ZSI 21337 and two female paratypes ZSI 21335, ZSI 21336) which were collected from Nagarjuna Hills (16³1'N; $\left.79^{\circ} 14^{\prime} \mathrm{E} ; 105 \mathrm{~m}\right)$ in Guntur District, Andhra Pradesh State, India (Sharma 1976, 2003; Gupta et al. 2012; Ganesh et al. 2013; Seetharamaraju \& Srinivasulu 2013). Sharma (1976, 2003) states that this species is diurnal and found in rocky habitats covered in a mix of evergreen and deciduous xerophytic vegetation. Judging from his dissection of the female specimen, Sharma (1976) remarked that this species preys upon gecko (Hemidactylus brookii). The climate of the type locality is described as hot and dry from March to October, with rainfall during the southwest, and north-east monsoons between November and February (Sharma 1976).

After several decades of obscurity, this species was recently reported from the Seshachalam Hills in southern Andhra Pradesh (Gupta et al. 2012), Golconda Fort Complex in Hyderabad City, Devarakonda in Nalgonda District, both situated in central Andhra Pradesh (Ganesh et al. 2013; Seetharamaraju \& Srinivasulu 2013) and Thally in Krishnagiri District, northern Tamil

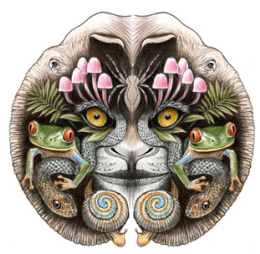

ISSN

Online 0974-7907 Print 0974-7893

OPEN ACCESS Nadu (Ganesh et al. 2013). In addition to reporting new localities for Coluber bholanathi, Gupta et al. (2012) provided the first in-life illustration of this species, Seetharamaraju \& Srinivasulu (2013) elaborated on the hemipineal morphology of the species as described by Sharma (2003) and Ganesh et al. (2013) provided the first illustration of the holotype while clearing up some confusion about its type registration number. Cumulatively, these three works have shed some light on this poorly-understood species.

In this note we provide the first report of Coluber bholanathi from the Gingee Hills, Villupuram District, northeastern Tamil Nadu. The snake which was $\sim 40 \mathrm{~cm}$ long (Image 2), was photographed by A. Mohanty on the morning of 6 December 2004 on a rocky hillock $\left(12^{\circ} 06^{\prime} 16^{\prime \prime} \mathrm{N}, 79^{\circ} 22^{\prime} 46^{\prime \prime} \mathrm{E} ; 115 \mathrm{~m}\right)$ overlooking the Panamalai Lake (Image 1; Table 1). This lake is one of the many reservoirs that are scattered along the scenic Gingee Hills that run parallel to the east coast of Tamil Nadu. The Gingee Hills, which are a discontinuous southern extension of the Eastern Ghats, are a mixture of dry deciduous scrub forest and thorn scrub (Ramamurthy 1962; Champion \& Seth 1968).

The snake was observed and photographed at a distance of $\sim 50 \mathrm{~m}$ away before it escaped into a series of boulders. We used the photograph provided in this note (Image 2) and three more, which provided several

DOI: http://dx.doi.org/10.11609/JoTT.o3628.5671-4 | ZooBank: urn:Isid:zoobank.org:pub:D9DFC535-B245-4B3A-BFB9-483970D4A11C

Editor: Raju Vyas, Vadodara, Gujarat, India.

Date of publication: 26 April 2014 (online \& print)

Manuscript details: Ms \# 03628 | Received 15 May 2013 | Final received 17 April 2014 | Finally accepted 18 April 2014

Citation: Smart, U., E.N. Smith, B.H.C.K. Murthy \& A. Mohanty (2014). Report of Nagarjunasagar Racer Coluber bholanathi Sharma, 1976 (Squamata: Serpentes: Colubridae) from the Gingee Hills, Tamil Nadu, India. Journal of Threatened Taxa 6(4): 5671-5674; http://dx.doi.org/10.11609/JoTT.o3628.5671-4

Copyright: (C) Smart et al. 2014. Creative Commons Attribution 4.0 International License. JoTT allows unrestricted use of this article in any medium, reproduction and distribution by providing adequate credit to the authors and the source of publication.

Funding: None.

Competing Interest: The authors declare no competing interests.

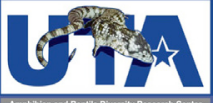

Acknowledgements: We would like to thank the director of the Zoological Survey of India for allowing us to examine the holotype and paratypes of $C$. bholanathi. We would also like to thank Coleman M. Sheehy III for his valuable inputs to the manuscript. Vivek Sharma and Pratik Pradhan are thanked for their prompt and informative correspondence, and Paul P. Pasichnyk is thanked for his help with editing the images. 


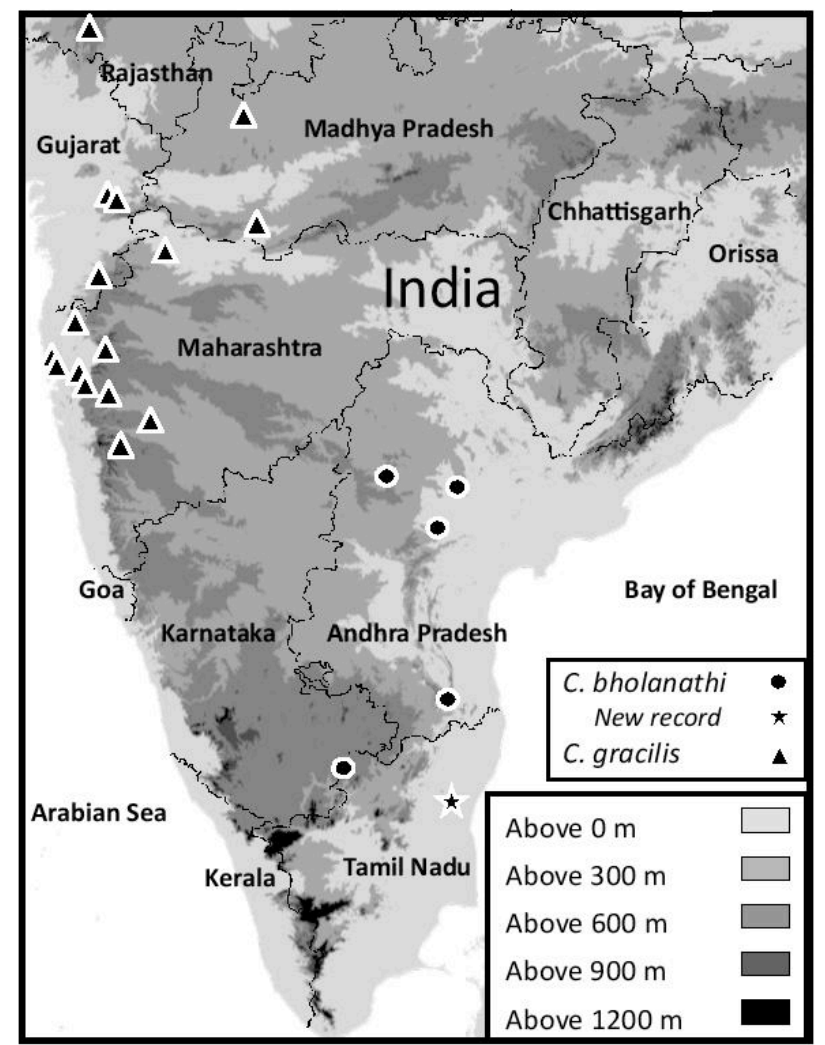

Image 1. Distribution map of Coluber bholanathi and Coluber gracilis in peninsular India.

different angles of the animal, to identify the snake as Coluber cf. bholanathi based on color pattern and dorsal scale rows at one head-length behind the head, at midbody, and at one head-length anterior to the vent. Due to $C$. bholanathi's close resemblance to $C$. gracilis, we also examined the type specimens of $C$. bholanathi. Coluber gracilis (Günther 1862) is another Indian species of Coluber, reported only from a few localities in the Satpura mountain ranges and northern Western Ghats from the states of Gujarat, Maharashtra, Madhya Pradesh and Rajasthan (Mahendra 1948; Ingle 2002; Sharma 2003; Whitaker \& Captain 2004; Vyas et al. 2011; Walmiki et al. 2012; Table 1). It's found in similar habitat type as C. bholanathi, e.g., rocky habitats with sparse, low, and thorny vegetation, although it is also reported to inhabit plains and open fields (Ingle 2002).

After close examination of the photographs, digital sharpening, and identifying the approximate midline of the animal, we found that the dorsal scales of the observed specimen from Gingee Hills were in (no more than) 19:19:17 rows. This count is closer to that observed in C. bholanathi (19:19:15 rows) than it is to $C$. gracilis (21:21:15 rows) (Sharma 1976). We observed additional differences in the patterning of the nuchal, oval blotch; in C. gracilis, the blotch appears to usually have an inverse $\mathrm{V}$ at its posterior margin (Image 3), whereas in C. bholanathi, the posterior margin tends to be either round or it fuses with the subsequent blotch forming a single large and elongate blotch (Image 5). The Gingee specimen has a nuchal blotch that has a round posterior margin, as observed in several specimens, including the type of $C$. bholanathi (Image 2). Moreover, C. bholanathi and the Gingee Hills specimen both possess a dark brown parietal bar that is interrupted laterally by light coloration at the post-temporal area adjacent to the parietal scales. In C. gracilis, however, the dark parietal bar widens towards the last two supralabials, typically forming an inverted " $Y$ " (Image 4).

Based on similarities in diagnostic morphological characters (namely: dorsal scale counts, nuchal marking and color pattern) and the geographic proximity of verified records (Gupta et al. 2012; Ganesh et al. 2013), we identified the Coluber from Gingee Hills as $C$. bholanathi. Our new record extends the known range of the species by $495 \mathrm{~km}$ south of the type locality and $194 \mathrm{~km}$ south-east of the southernmost locality (Ganesh et al. 2013). Our note also provides encouraging prospects that the geographic range of this obscure and rare species is probably larger than documented and we propose that the Gingee hills and adjacent suitable habitat warrant a more thorough sampling.

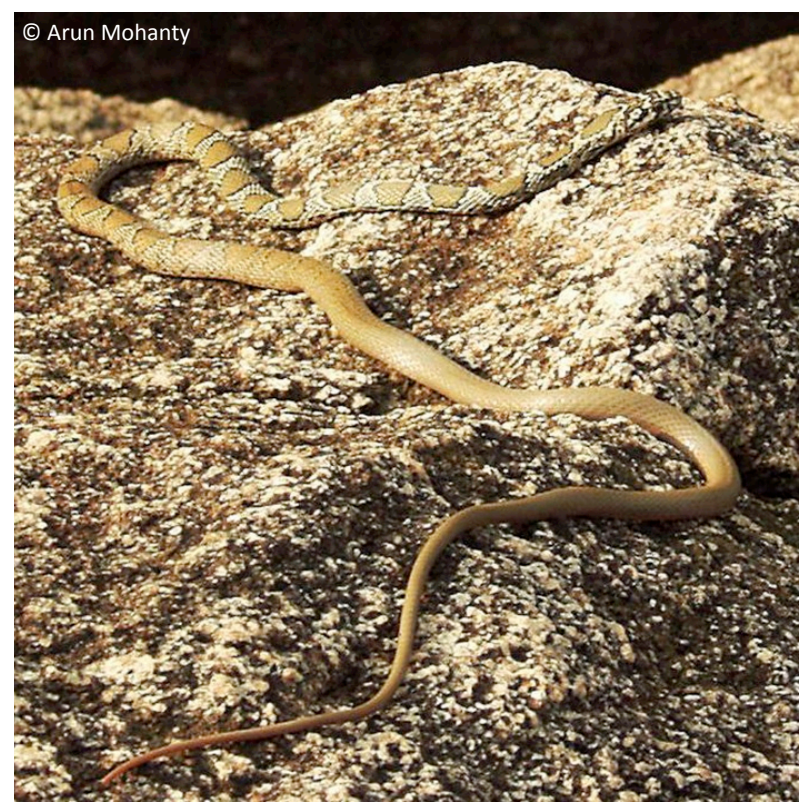

Image 2. Coluber bholanathi in the rocky landscape of Gingee Hills in northern Tamil Nadu 
Table 1. Localities based on personal observation and literature for Coluber bholanathi and Coluber gracilis. The longitude and latitude for the rows with an * are published in literature, for every other locality we provide the coordinates of the city that is mentioned.

\begin{tabular}{|c|c|c|c|c|c|c|}
\hline Species & State & Location & Latitude & Longitude & Elevation & Reference \\
\hline \multirow[t]{6}{*}{ C. bholanathi } & Andhra Pradesh & Nagarjuna Hills (Guntur District) & $16^{0} 31^{\prime} 00^{\prime \prime} \mathrm{N}$ & 79014'00"E & $105 \mathrm{~m}$ & Sharma $1976 *$ \\
\hline & & $\begin{array}{l}\text { Seshachalam Hills (Chittoor } \\
\text { District) }\end{array}$ & $13^{0} 39^{\prime} 00^{\prime \prime} \mathrm{N}$ & $79^{\circ} 25^{\prime} 00^{\prime \prime} \mathrm{E}$ & $175 m$ & Guptha et al. 2012* \\
\hline & & $\begin{array}{l}\text { Golkonda Fort Complex, } \\
\text { Hyderabad (Hyderabad District) }\end{array}$ & $17^{0} 22^{\prime} 58^{\prime \prime} \mathrm{N}$ & $78^{\circ} 24^{\prime} 03^{\prime \prime} \mathrm{E}$ & Not Available & $\begin{array}{l}\text { Seetharamaraju \& } \\
\text { Srinivasulu 2013* }\end{array}$ \\
\hline & & Devarakonda (Nalgonda District) & $17^{0} 10^{\prime} 00^{\prime \prime} \mathrm{N}$ & 79033'00"E & $270 m$ & Ganesh et al. 2013* \\
\hline & Tamil Nadu & Thally (Krishnagiri District) & $12^{\circ} 34^{\prime} 60^{\prime \prime} \mathrm{N}$ & $77^{0} 39^{\prime} 00^{\prime \prime} \mathrm{E}$ & 920m & Ganesh et al. 2013* \\
\hline & & Gingee Hills (Villupuram District) & $12^{\circ} 06^{\prime} 16^{\prime \prime} \mathrm{N}$ & $79^{\circ} 22^{\prime} 46^{\prime \prime} \mathrm{E}$ & $115 \mathrm{~m}$ & $\begin{array}{l}\text { Smart et al. } 2014 \\
\text { (current study) }\end{array}$ \\
\hline \multirow[t]{16}{*}{ C. gracilis } & Rajasthan & Udaipur (Udaipur District) & $24^{0} 34^{\prime} 17^{\prime \prime} \mathrm{N}$ & $73^{\circ} 41^{\prime} 30^{\prime \prime} \mathrm{E}$ & Not Available & $\begin{array}{l}\text { Sharma \& Nagar } \\
\text { 2007* }\end{array}$ \\
\hline & Madhya Pradesh & Asirgarh (Burhanpur District ) & $21^{\circ} 29^{\prime} 06^{\prime \prime} \mathrm{N}$ & $76^{0} 16^{\prime} 50^{\prime \prime} \mathrm{E}$ & Not Available & Vyas et al. 2011* \\
\hline & & Ujjain (Ujjain District) & $23^{\circ} 10^{\prime} 45^{\prime \prime} \mathrm{N}$ & $75^{\circ} 47^{\prime} 06^{\prime \prime} \mathrm{E}$ & Not Available & Ingle 2003 \\
\hline & Gujarat & $\begin{array}{l}\text { Narmada Damn (Narmada } \\
\text { District) }\end{array}$ & $21^{\circ} 50^{\prime} 09^{\prime \prime} \mathrm{N}$ & $73^{\circ} 44^{\prime} 37^{\prime \prime E}$ & $50-60 \mathrm{~m}$ & Vyas et al. 2011* \\
\hline & & $\begin{array}{l}\text { Narmada River Bridge (Narmada } \\
\text { District) }\end{array}$ & $21^{\circ} 51^{\prime} 50^{\prime \prime} \mathrm{N}$ & $73^{\circ} 42^{\prime} 01^{\prime \prime E}$ & $50-60 \mathrm{~m}$ & Vyas et al. 2011* \\
\hline & & $\begin{array}{l}\text { Vansada National Park, near } \\
\text { Waghai river (Navsari District) }\end{array}$ & $20^{\circ} 41^{\prime} 51^{\prime \prime} \mathrm{N}$ & $73^{\circ} 31^{\prime} 48^{\prime \prime E}$ & $110-360 \mathrm{~m}$ & Walmiki et al. 2012* \\
\hline & Maharashtra & Satara (Satara District) & $17^{\circ} 41^{\prime} 29^{\prime \prime} \mathrm{N}$ & $74^{\circ} 00^{\prime} 03^{\prime \prime} \mathrm{E}$ & Not Available & Vyas et al. 2011 \\
\hline & & Phaltan (Satara District) & $17^{0} 59^{\prime} 00^{\prime \prime} \mathrm{N}$ & $74^{\circ} 26^{\prime} 00^{\prime \prime} \mathrm{E}$ & Not Available & $\begin{array}{l}\text { Whitaker \& Captain } \\
2004\end{array}$ \\
\hline & & Koyna (Satara District) & $19^{0} 38^{\prime} 15^{\prime \prime N}$ & $73^{\circ} 10^{\prime} 11 " \mathrm{E}$ & Not Available & Vyas et al. 2011 \\
\hline & & Lonavala (Pune District) & $18^{\circ} 44^{\prime} 51^{\prime \prime} \mathrm{N}$ & $73^{\circ} 24^{\prime} 12^{\prime \prime} \mathrm{E}$ & Not Available & Vyas et al. 2011 \\
\hline & & Nane Ghat (Pune District) & $19^{\circ} 17^{\prime} 51 " \mathrm{~N}$ & $73^{\circ} 41^{\prime} 12^{\prime \prime} \mathrm{E}$ & Not Available & $\begin{array}{l}\text { Whitaker \& Captain } \\
2004\end{array}$ \\
\hline & & Pune District & Not Available & Not Available & Not Available & $\begin{array}{l}\text { Whitaker \& Captain } \\
2004\end{array}$ \\
\hline & & $\begin{array}{l}\text { Mumbai ( Mumbai City and } \\
\text { Suburban Districts) }\end{array}$ & $19^{\circ} 04^{\prime} 34^{\prime \prime} \mathrm{N}$ & $72^{\circ} 52^{\prime} 40^{\prime \prime} \mathrm{E}$ & Not Available & $\begin{array}{l}\text { Vivek Sharma pers. } \\
\text { comm. } 2012\end{array}$ \\
\hline & & Dhule (Dhule District) & $20^{\circ} 53^{\prime} 59^{\prime \prime} \mathrm{N}$ & $74^{\circ} 46^{\prime} 11^{\prime \prime} \mathrm{E}$ & Not Available & $\begin{array}{l}\text { Prateek Pradhan pers. } \\
\text { comm. } 2012\end{array}$ \\
\hline & & Borivali (Mumbai District) & $19^{\circ} 13^{\prime} 48^{\prime \prime} \mathrm{N}$ & $72^{\circ} 52^{\prime} 00^{\prime \prime} \mathrm{E}$ & Not Available & Vyas et al. 2011 \\
\hline & & Matheran (Raigad District) & $18^{\circ} 59^{\prime} 00^{\prime \prime} \mathrm{N}$ & $73^{\circ} 16^{\prime} 00^{\prime \prime} \mathrm{E}$ & Not Available & Vyas et al. 2011 \\
\hline
\end{tabular}

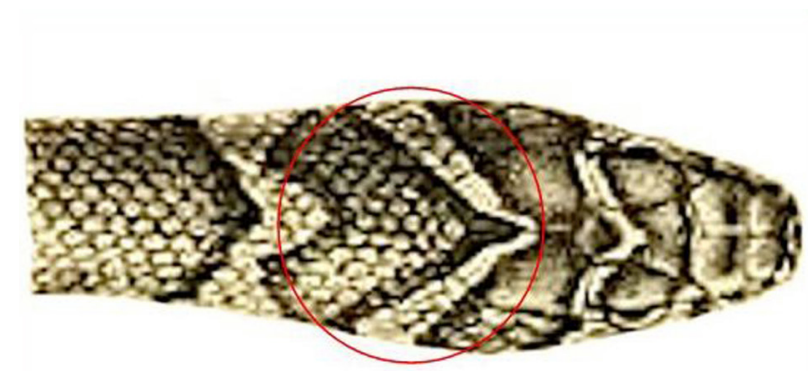

Image 3. Dorsal head pattern of Coluber gracilis as depicted by Günther (1862). Notice the V-shaped nuchal blotch (highlighted by red circle).

\section{References}

Gupta, B., N.V.S. Prasad \& D. Veerapan (2012). Rediscovery and range extension of Coluber bholanathi Sharma, 1976 from Seshachalam Hills, Andhra Pradesh, India. Herpetology Notes 5: 447-448.

Champion, H.G. \& S.K. Seth (1968). A Revised Survey of the Forest Types of India (Vol. 1). Manager of Publications, Delhi, India, 404pp. Ganesh, S.R, D. Adimallaiah \& P.K. Kailash (2013). New locality record of Nagarjun Sagar Racer Snake Coluber bholanathi Sharma, 1976. Herpetotropicos 9(1): 9-12.

Günther, A. (1862). On new species of snakes in the collection of the British Museum. The Annals and Magazine of Natural History Series 3(9): 124-132pp.

Ingle, M. (2002). Ecology and Status of the ophiofauna of eight districts of the Malwa region of MP. Cobra 50: 1-17. 


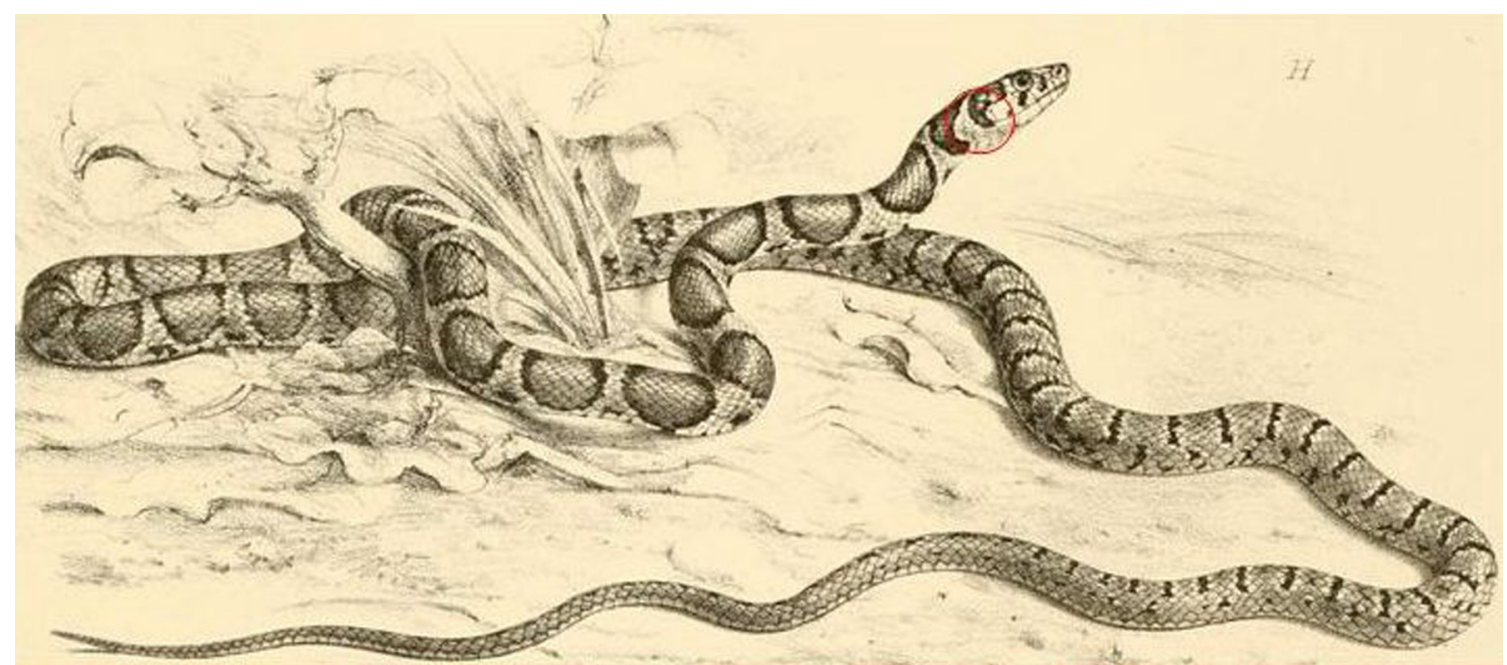

Image 4. Coluber gracilis as depicted by Günther (1862). Notice how the dark parietal bar widens towards the last two supralabials, forming an inverted "Y" (highlighted by red circle).
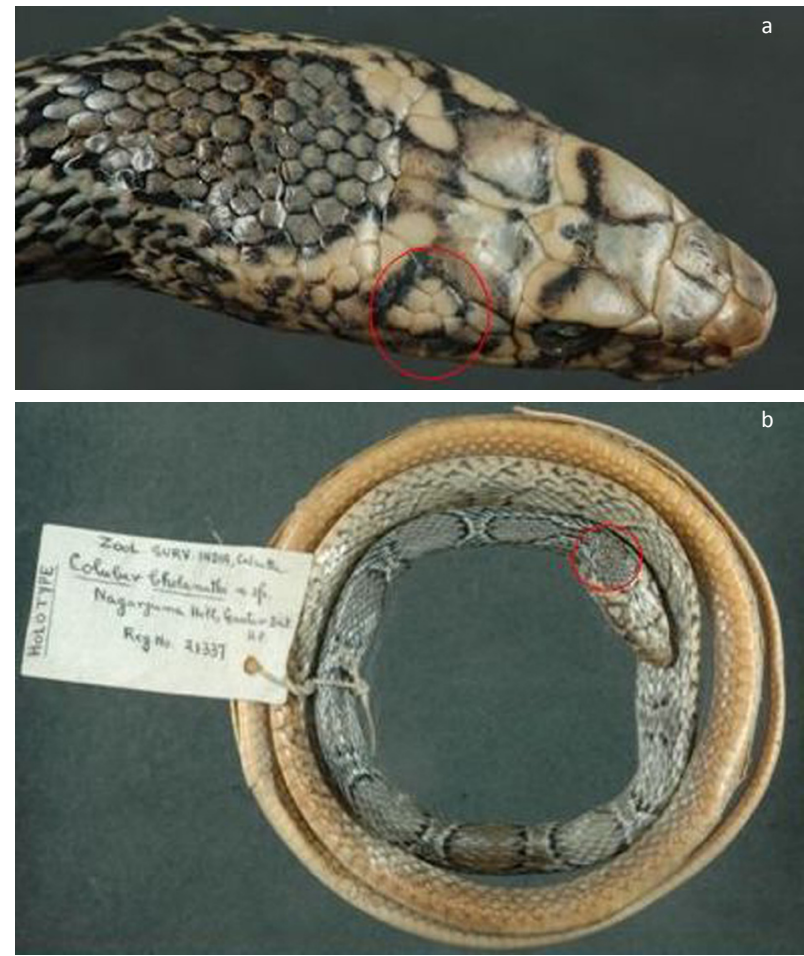

Image 5. Dorsal pattern of head (a) and body (b) of holotype of Coluber bholanathi, ZSIC 21337. Notice the presence of light coloration in the temporal area (a) and the round nuchal blotch (b) (highlighted by red circles).
Mahendra, B.C. (1984). Handbook of the Snakes of India, Ceylon, Burma, Bangladesh and Paskistan. Vol. XXII. The Annals of Zoology. The Academy of Zoology, Khandari Road Agra -2, India, 412pp.

Ramamurthy, K. (1962). Ecological studies of the vegetation of Gingee Reserve Forest, South Arcot District, Madras State. Proceedings of the Indian Science Congress 49: 319-320.

Seetharamaraju, M. \& C. Srinivasulu (2013). Discovery and description of male specimen of Coluber bholanathi Sharma, 1976 (Reptilia: Colubridae) from Hyderabad, India. Taprobanica 5(1): 32-35; http:// dx.doi.org/10.4038/tapro.v5i1.5659

Sharma, R.C. (1976). Some observations on ecology and systematics of Coluber bholanathi, a new species of snake (Reptilia: squamata: Colubridae) from India. Comparative Physiology and Ecology 1(3): 105-107.

Sharma, R.C. (2003). Handbook, Indian Snakes. Zoological Survey of India, Kolkata, India, 292pp.

Sharma, S.K. \& S. Nagar (2007). First record of Slender Racer Coluber gracilis (Gunther, 1862) (Serpents: Colubridae) from Rajasthan. Journal of the Bombay Natural History Society 104(3): 355.

Vyas, R., V.V. Patel \& M.N. Thakur (2011). Records of the Slender Racer, Coluber gracilis (Günther, 1862), from Gujarat State with notes on its distribution. Sauria 33(2): 51-56.

Walmiki, N., A. Kumbhar \& B. Gupta (2012). Range Extension of Slender Racer (Coluber gracilis Gunther, 1862) in India. World Journal of Zoology 7(4): 303-305.

Whitaker, R. \& A. Captain (2004). Snakes of India, The Field Guide. Draco Books, Chengalpattu, Tamil Nadu, India, 385pp. 